\title{
Student Attitudes toward Information Systems Management as Major and Career Options
}

\author{
Zachary Wong
}

\begin{abstract}
In today's world of fast paced technology growth and the ability in incorporating information technology (I.T.) into business, students who desire careers in Information Systems Management (ISM) are declining. The decline is due to a number of causes, including outsourcing of jobs and recent lackluster economic activity. Information Systems Management is a major where students study how to analyze, design or prescribe and manage systems which integrate data a company creates into value-addedand usable information for use at the management level. Information Systems professionals' foci include but not limited to, managing databases for a company and ascertaining that data captured and maintained within the databases and systems provides integrity and value. Careers in Information Systems Management has high job security in today's marketplace and a higher than average salary. But, there is a stigma associated with those career options and it is preventing current generation of students from considering the major. There has been such a severe shortage of trained professionals within the field of Information Systems Management that companies have to continue to outsource because there are relatively few or no qualified individuals available domestically for hire. The main reasons for the decline are students' misperception of Information Systems Management as a field of study and that young college entrants are not educated aboutits career possibilities and future prospects in the field.
\end{abstract}

Index Terms - Career, information systems, major.

\section{INTRODUCTION}

Typically, university programs experience enrollment trends over several decades, with numbers rising and falling depending on the economy as well asrespective fields' prevailing job market. Most business school students strive to obtain degrees in promising fields so that they might land on a stable career with high salary. Their choice of major reflects where they believe success is most likely to be found [1].

In the recent decade, colleges and universities in the United States have experienced a nation-wide decline in the number of students electing to pursue a degree in Information Systems Management (ISM), despite it being a major in which graduates generally have three or four job offers and starting salaries higher than other business disciplines offer [2]. Information Systems

Management (ISM) is also known across the academia by other names such as, Computer Information Systems, Management Information Systems, and Business Information Systems. Although Information Technology

Manuscript received March 6, 2014; revised May 19, 2014.

Zachary Wong is with Sonoma State University, USA (e-mail: zachary.wong@sonoma.edu).
(I.T.) is term that is often used interchangeably with Information Systems in many contexts, it refers to the technological components that comprise a computerized information system. If anything, ISM programs should be impacted, and yet the number show that enrollment has tremendously dipped in recent years even with seemingly advantageous opportunities available to ISM majors. The question of concern would then be, why? Why would students choose to forego pursuing a degree in a discipline so full of opportunities and how that is affecting the U.S. educational institutions as well as the U.S. information technology industry?

In the 1990s, there was an increase in the number of students majoring in Information Systems Management [3]. That could be attributed to the fact that students believed that there was money to be made and an abundance of jobs to be held. Yet, since the turn of the century, there has been a significant and steady drop in enrollment. A reason for this is the change in perspective toward the I.T. industry. The dot-com bust has led many students to believe that there is lack of a bright future for them if they major in Information Systems Management [4]. However, such assumption is improper based on the country's demand for Information Systems and data management trained professionals.

The U.S. Department of Labor [5] claimed that high level jobs that combine technical and business skills are still abundant in the United States. Nonetheless, since year 2000 to date, most Information Systems Management programs in the country have experienced enrollment decrease by one-half or more. In a survey of colleges and universities that offer Information Systems related degrees, $76 \%$ reported that enrollment had dropped in recent years. Of those surveyed, $67 \%$ blamed the outsourcing of jobs, $60 \%$ blamed the economy in general, $60 \%$ blamed the dot-com failure, $40 \%$ blamed the cycle of nature, and $27 \%$ blamed the decline in students' analytical abilities [6]. According to Walstrom and colleagues [7], this generation, which is noted for its pervasive use of technology, has little interests in, or awareness of, the occupations that drive the digital age. However, there also are students who considered a computer-related major but did not pursue it. In a survey of 51 such subjects, $18 \%$ said that they could not find enough information about computer-related careers, $24 \%$ thought the rigor required of the program would be too hard for them to handle, 26\% said they thought it would be too technical, $45 \%$ said they did not think that they would like the work, $13 \%$ said they did not think the employment prospects were good, and $8 \%$ cited "other" as reasons [8].

Other researches in the topic [6], [9] have also found similar reasons for the decline. In general, students believe they will not succeed in the Information Systems 
Management careers due to a lack of job security. They fear that jobs in those fields would be outsourced oroffshored. With all the media hype about people losing jobs because of outsourcing of the jobs to foreign countries, students' fear might appear justified. Another factor influencing students to refrain from majoring in Information Systems Management has been the lack of interestsin and the perceived level of difficulty associated with the major. It is no easy task to become familiar with information technology and systems and their ever changing technological standards. Overcoming such intimidation has also been a major challenge for instructors and the institutions of higher learning across the United States. Moreover, with the decrease in enrollment in and funding provided to Information Systems Management programs, many colleges and universities simply do not have ample resources to deliver smaller class sizes that would foster a good learning environment for students.

Because many schools' funding is based on enrollment, a decline in Information Systems Management course hours registered can directly affect how the budget is allocated.
This can also mean that there will be less money available for Information Systems Management programs. The loss of money leads to a decrease in staff, resources, course offerings, and can create roadblocks in providing the latest technology. Drastic declines in enrollment can lead to complete elimination of programs. So when departments suffer a budget cut, they can lose their degree program desirability and competitive edge in the market place of the academia. If U.S. educators cannot produce a qualified workforce, the country would realize an imbalance in the marketplace. Presently, there is a severe shortage of qualified candidates in a growing economy. Some may view this as a good thing because there are fewer people competing for jobs. However, beyond those reasons mentioned, the country does risks the cultivation of an ineffective workforce, if any.For companies that need in-house experts, they would have no choice but to import talents from abroad. However, to do so may not always be easy due to complex immigration policy and procedures.

TABLE I: BEST 100 JOBS IN AMERICA: INFORMATION SYSTEMS RELATED

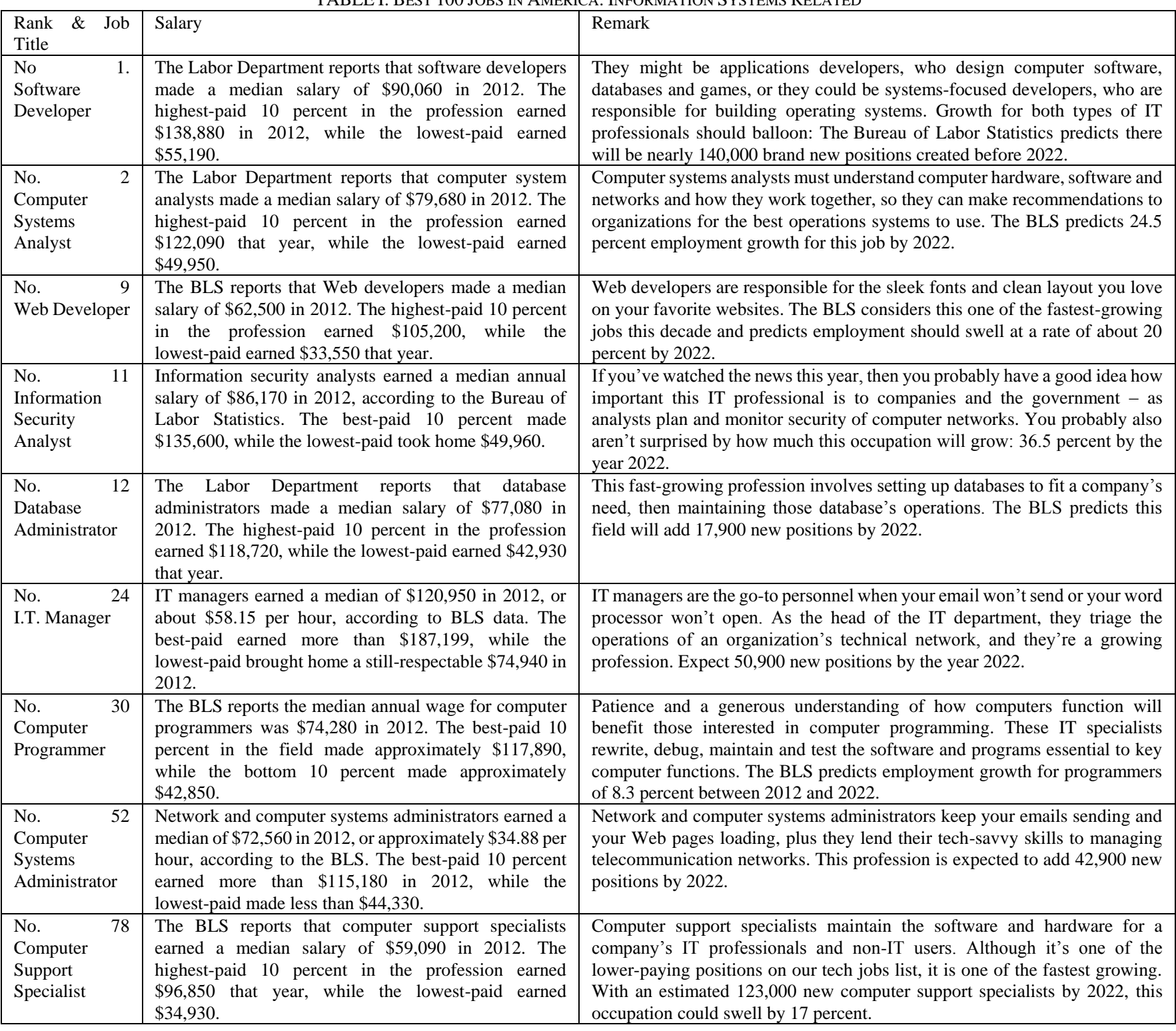

The majority of research in offshore I.T. outsourcing has been focused on justifying how it will help both outsourcer and its partners in a win-win situation. There has been little attempt to study the potential socio-economic loss from 
outsourcing. Various studies conducted over the last ten years have shown that outsourcing allows firms to reduce high overhead costs and improve flexibility, and thus improve overall performance of the firm. However, offshore I.T. outsourcing brings new challenges and risks. The skeptics believe that outsourcing may weaken the business competiveness of the region, investors' confidence in investing in local businesses, and may create a spiral effect on economic indicators such as unemployment, enrollment in schools, living styles, housing, and construction. A survey of Information Systems Management professionals also found that over ninety percent were concerned that data security issues and privacy issues would increase as a result of offshore IS outsourcing [10].

One might wonder whether Information Systems Management is still a good career choice for students and workers in a country that offshores I.T. related work. Despite all the publicity in the United States about jobs being lost to India and China, the size of the I.T. employment market in the United States today is higher than it was at the height of the dot-com boom [11], [12].

\section{CAREER PROSPECTS IN INFORMATION SYSTEMS MANAGEMENT}

Both Money Magazine and Salary.com [8] have compiled a list of the top ten best jobs in America: 1). Software Engineer, 2). College Professor, 3). Financial Advisor, 4). Human Resource Manager, 5). Physician Assistant, 6). Market Research Analyst, 7). Computer Information Technology Analyst, 8). Real Estate Appraiser, 9). Pharmacist, 10). Psychologist. Out of those top ten careers, two are directly related to I.T. and more than half of them will be indirectly affected by the decline in information systems professionals available in the economy.

More recently, according to US News and World Report [12] in Table I, it has been reported that nine out of the best 100 jobs in the United States are directly related to Information Systems. Out of those nine jobs, three are ranked in the top ten. Table I provides a summary of literature published. Based on the report, careers in Information Systems Management should provide outstanding long-term job security, salary prospects and prestige. Many fields now seek professionals with in-depth knowledge of information systems management and often depend heavily on the feedback produced by information systems. In the age of digital information, expertise in information systems management has become highly valued.

\section{RESEARCH MethodOlOGY AND RESUltS}

In an attempt to unveil the current generation students' attitudes toward Information Systems Management as a major of choice, 93 subjects taken from a second year pre-business program at a San Francisco Bay Area school participated in a survey study consisting of two phases. In the first phase, subjects were asked whether they were familiar with what Information Systems Management as a major entailed in general. Based on their responses, subjects were allocated into three categories prior to conducting phase two of the survey. The three categories were:

1) Subjects who have never heard of ISM as a major

2) Subjects who have heard of ISM but are not familiar with what it entails

3) Subjects who have heard of ISM and are knowledgeable with what it entails

Before commencement of the second phase of survey, each and every subjects allocated to all three categories were provided Table I above consisting of Information Systems Management related careers listed in US News and World Report's Best 100 Jobs in the United States (2014 edition). Next, subjects were given a 30 minute period to digest the information and for a question-and-answer session hosted by a full professor in the ISM field to answer any queries the subjects might have. Finally, all subjects were provided with a common questionnaire to capture their written responses.

Below are the results compiled after completion of the two-phase survey (in Table II, Table III, Table IV, Table V):

TABLE II: DISTRIBUTION OF SUBJECTS ACCORDING TO FAMILIARITY WITH ISM

\begin{tabular}{|l|l|l|}
\hline Subjects Who Never Heard of ISM & 36 & $38.7 \%$ \\
\hline $\begin{array}{l}\text { Subjects Who Have Heard of ISM but } \\
\text { Unfamiliar with ISM }\end{array}$ & 40 & $43 \%$ \\
\hline $\begin{array}{l}\text { Subjects Who Were Knowledgeable about } \\
\text { ISM }\end{array}$ & 17 & $18.3 \%$ \\
\hline Total & 93 & $100 \%$ \\
\hline
\end{tabular}

TABLE III: BREAKDOWN OF RESPONSES: SUBJECTS WHO NEVER HEARD OF

\begin{tabular}{|c|c|c|}
\hline $\begin{array}{l}\text { Expressed interests in Majoring } \\
\text { in ISM }\end{array}$ & 15 & $\begin{array}{l}\text { Good } \quad \text { Salary: } 3 \\
\text { Promising } \quad \text { Prospects: } \\
\text { 11 } \\
\text { Other: } 1\end{array}$ \\
\hline $\begin{array}{l}\text { Expressed NO } \\
\text { Majoring in ISM }\end{array}$ & 8 & $\begin{array}{lr}\text { No Interests } & \text { in } \\
\text { Computers: } & 6 \\
\text { No Confidence: } & \mathbf{2} \\
\text { Other: } 0 & \end{array}$ \\
\hline $\begin{array}{l}\text { Expressed Needs for } \text { More } \\
\text { Information about ISM }\end{array}$ & 13 & \\
\hline
\end{tabular}

TABLE IV: BREAKDOWN OF RESPONSES: SUBJECTS WHO HAD HEARD OF ISM BUT UNFAMILIAR WITH ISM

\begin{tabular}{|l|l|l|}
\hline $\begin{array}{l}\text { Expressed interests in Majoring } \\
\text { in ISM }\end{array}$ & 22 & $\begin{array}{l}\text { Good Salary: 7 } \\
\text { Promising Prospects: } \\
13 \\
\text { Other: } 2\end{array}$ \\
\hline $\begin{array}{l}\text { Expressed NO interests in } \\
\text { Majoring in ISM }\end{array}$ & 7 & $\begin{array}{l}\text { No Interests in } \\
\text { Computers: } 7 \\
\text { No Confidence: } 0 \\
\text { Other: 0 }\end{array}$ \\
\hline $\begin{array}{l}\text { Expressed Needs for More } \\
\text { Information about ISM }\end{array}$ & 11 & \\
\hline
\end{tabular}

TABLE V: BREAKDOWN OF RESPONSES: SUBJECTS WHO WERE KNOWLEDGEABLE ABOUT ISM

\begin{tabular}{|l|l|l|}
\hline $\begin{array}{l}\text { Expressed interests in Majoring } \\
\text { in ISM }\end{array}$ & 2 & $\begin{array}{l}\text { Good Salary: 0 } \\
\text { Promising Prospects: 2 } \\
\text { Other: 0 }\end{array}$ \\
\hline $\begin{array}{l}\text { Expressed NO interests in } \\
\text { Majoring in ISM }\end{array}$ & 14 & $\begin{array}{l}\text { No Interests in } \\
\text { Computers: 5 } \\
\text { No Confidence: } 2 \\
\text { Other: 7 }\end{array}$ \\
\hline $\begin{array}{l}\text { Expressed Needs for More } \\
\text { Information about ISM }\end{array}$ & 1 & \\
\hline
\end{tabular}

First, results show that less than one-fifth of subjects surveyed had concise knowledge of what ISM as a major and career entailed. Stunningly, more than one-third of subjects had never heard of ISM at all. After subjects were provided 
with information provided in Table I (Best 100 Jobs in the U.S.: Information Systems Related) and any queries about ISM as a major and career entailed, majority of subjects who expressed an interest in majoring in ISM cited bright career prospects as the primary reason. Contrary to general belief however, good salary did not appear to be a top factor in their decision to consider ISM as a major or career field. Of those who indicated no interests in pursuing a major in ISM, a lack of interests in computers was by far the most frequently cited reason. Worthy of noting was that among subjects who were knowledgeable in ISM but expressed no interests in considering ISM, five indicated "other" as reason. Three of those subjects indicated on their survey questionnaires that it was because ISM is a field dominated by foreigners. One apparent flaw with the survey questionnaire was that subjects were not encouraged to indicate reasons when indicating "No Confidence" as reason. Hence, it was unclear what subjects' concerns were although it could be speculated that subjects could either be propelled by the academic rigor required of the major or it could have due to their perception that ISM is a field dominated by foreigners, similar to the responses indicated by the subject group who were knowledgeable about ISM.

\section{DISCUSSION}

Most university students do not know that today's top companies heavily seek after workers trained in Information Systems Management. The recession that hit the U.S. technology economy during 2001 - 2003 has created a myth about how all information systems related jobs are becoming outsourced resulting in a general belief that there is no future domestically for a career in the field. During that time, the media often reported many stories about waves of layoffs for I.T. personnel, which were replaced by outsourcing [4]. It is easy to see how a generation of new students would be turned off to the idea of majoring in Information Systems Management when all they heard during high school and in college was how there were no new jobs in the field and that any new ones created would be outsourced almost assuredly.

Although it is true that many information systems related jobs have been outsourced or offshored, many companies are finding that having face-to-face interaction about their specific system is vital if the system is to run fluidly. A person running the system overseas would have a communication barrier such as only being able to speak over the phone and anytime the system needs to be tweaked then it could cause delays due to different time schedules. It is important for people to understand that these jobs are more complicated than people give them credit for and it is essential for a domestic professional with strong communication and management skills to take direct and real-time control of the information systems.

Another reason for poor enrollment into Information Systems Management degree programs is poor high school advising [10]. College counsellors routinely planning for students to get into college do not spend enough time counselling them about what students actually want to do. Also, since Information Systems Management is a relatively new field, counsellors may not know enough about the field, they could run into preaching the common misconception that there are not enough jobs available in the marketplace or that their jobswill be outsourced. Consequently, that could cause ill-informed student to stay away from the major resulting in the downsizing or elimination of Information Systems Management departments in colleges and universities. This combined with the fact that students are noticing how many universities are not offering an ISM major program, many students would be led to believe that something is wrong with the field and that it would be a waste of time to pursue the major.

Many colleges and universities in the U.S. are now making the decisions on whether or not they should commence or continue to offer a major that no one wants to major in [13]. While enrollment may be dwindling at most schools, others are outright dropping the program from their schools even with students enrolled in the major. If there were only a few students in any major, it is expected that the college or university is going to consider changing or removing the program to benefit more people. It is a shame that so many colleges and universities would or have already closed their doors to Information Systems Management when they only opened the doors as early as a decade or so ago. They are not allowing a rebound of student enrollments. Instead, many are stifling the revival of the program and making it more difficult for dedicated students who are trying to pursue their passion as an ISM professional. Students who are now graduating from these dying programs are sure to leave school with a bad recollection of their college experience as well. When a student graduates from a program that was cut while they were enrolled, they are most likely not going to recommend the program highly to another. It would also make them think that their major is not valuable because colleges and universities across the country are cutting their programs which to them would mean that companies are not hiring in that area anymore.

The offshoring of jobs from the United States is also a real issue that must be addressed promptly. Offshoring of information technology jobs is a sign of an American organization not believing in its own country's workforce. Moving information technology positions outside the United States is attractive for many organizations because of the consistently low cost. An initial reason for outsourcing of information technology jobs to places like India was the labor shortage in the United States. However, this was not entirely true. There was a labor shortage in India as well [14]. This labor shortage brings the in the question of whether cost was the main reason. The issue of immigration also plays an important role in the shortage of Information Technology workers that leads to the offshoring of these positions. For example, H-1B Visas that grant temporary working permits are sometimes difficult to obtain. The more difficult is to get $\mathrm{H}-1 \mathrm{~B}$ Visas, the more likely that jobs will go abroad because it is impossible to import talents into or retain talents in the country that need the skills [15]. As a result, many of the talent and international student graduates of U.S. Information Systems Management programs whocouldhave stayed in the United States left because of immigration difficulties.

While immigration disputes and costs contribute to the offshoring of Information Technology jobs in the United 
States, increasing the enrollments in ISM programs continues to remain the key issue that is being faced today. According to Ken Hess [14], "The solution [for creating more Information Technology jobs] is to invest in our own infrastructure and our own people." Hess' solution is the most rational recommendation in bringing Information Jobs back to the United States. For example, if institutions of higher education and organizations invested in the American people, then step by step, the country could produce enough professionals to ensure that the United States would regaina comparative advantage in Information Technology.

\section{CONCLUSION}

There are several negative consequences beyond the obvious when IS enrollments continue to decline. That is not only affecting the domestic workforce, but the colleges and universities offering the programs themselves. While jobs in this industry have been outsourced abroad, the vast majority of them are needed domestically and as a result, companies are finding themselves under great pressured to bring in foreign talents because those foreign workers are better qualified than the local ones, if any. As a nation, the United States needs to produce a qualified and competitive workforce and not have to resort to importing workforce or outsourcing jobs abroad. The natural and preferred method of doing so is within the academic sector. Therefore, institutions of middle and highereducation need to re-evaluate their approach to reaching students and creating a desirable method in teaching those valuable skills. The process should start in high school counselling. Tertiary educators need to include Information Systems courses in a variety of combined minor options. Creativity, innovation and analysis are important factors when campaigning to the next generation of college students. These students need to be aware of the importance of understanding information systems management, its relevance in most areas of study, and the significance that Information Systems knowledge carries in the workplace. Without a knowledge base of what an Information Systems Management entails, most students are turned off by the idea due to their misconceptions of the field.

The world is fluid and changing, humanity's future lies within the exchange of information.

\section{REFERENCES}

[1] A. Kumar and P. Kumar, "An examination of factors influencing students' selection of business majors using TRA framework." Decision Sciences, vol. 11, no. 1, pp. 77-105, 2013.

[2] P. Parker. (2006). MIS Major Enrollment Continues to Decline. The Red and Black. [Online]. Available: http://www.redandblack.com

[3] L. Goff, "New trend: Tech is hot college major," Computerworld, July $11,2000$.

[4] J. Elam et al., "Reversing the landslide in computer-related degree programs," Communication of the ACM, vol. 53, no. 2, pp. 127-133, 2010.

[5] US Department of Labor. (2012). Occupational outlook handbook. [Online]. Available: http://www.bls.gov/OOH/computer and information technology/home.htm

[6] J. Russell et al., "Reversing the Decline of CIS Enrollment in Colleges and Universities by Creating Viable and Attractive Minors in CIS: A Statistical Study of CIS Minors at US Colleges and Universities," Information Systems Education Journal, vol. 7, no. 7, 2009.

[7] K. Walstrom et al., "Why are students not majoring in information systems?" Journal of Information Systems Education, vol. 19, no. 1, pp. 43-54, 2008.

[8] L. Pollacia and W. Lomerson, "Analysis of factors affecting declining CIS enrollment," Information Systems, International Association for Computer Information Systems, vol. 7, no. 1, pp. 220-225, October 2006

[9] J. Downey, R. McGaughey, and D. Roach, "Attitudes and influences toward choosing a business major: The case of information systems," Journal of Information Technology Education, vol. 10, pp. 232-251, 2011

[10] K. Knapp, S. Sharma, and K. King, "Macro-economic and social impacts of offshore outsourcing of information technology: practitioner and academic perspectives," International Journal of E-Business Research, vol. 3, no. 4, pp. 112-132, 2007.

[11] W. Aspray, F. Mayadas, and M. Y. Vardi, Globalization and Offshoring of Software: A Report of the ACM Job Migration Task Force, Association of Computing Machinery, 2006.

[12] US News and World Report. (2014). The 100 Best Jobs. [Online]. Available:

http://money.usnews.com/careers/best-jobs/rankings/the-100-best-job s.

[13] W. Kuechler, A. McLeod, and M. Simkin, "Filling the pipeline for IS professionals: What can IS faculty do?" Journal of Information Systems Education, vol. 18, no. 1, pp. 407-415, 2009.

[14] K. Hess, "The Current State of Technical Certification and IT Jobs in America," ZDNet. ZDNet, 19 May, 2013.

[15] S. Sengupta, "US Immigration Bill May Force Jobs to Be Shipped Overseas, Silicon Valley Executives Say," The Times of India, May 20, 2013.

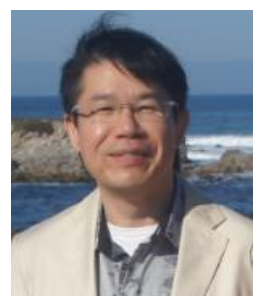

Zachary Wong is an area coordinator and a professor of business administration at Sonoma State University, California, USA. He is from Singapore and has been residing in the United States since the 1980s. He received a PhD in management information systems from The University of Mississippi and was inducted into six international honor societies. He has a future plan in returning to Asia and getting involved in the education industry 